\title{
An integrated approach to coastal rehabilitation: Mangrove restoration in Sungai Haji Dorani, Malaysia
}

\author{
Roslan Hashim, Babak Kamali, Noraini Mohd Tamin, Rozainah Zakaria
}

One of the most important problems in the coastal areas all over the world is erosion which has threatened human activities in the areas exposed to such hazard. Coastline retreat could result in very serious economic, environmental, and social impacts depending on the eroded area.

Over the past decades, as development has taken place in Malaysian coastal states, overlogging and clear-cutting of mangroves along coastlines has made coastal areas exposed to natural phenomena such as tidal inundation, storm surges, currents, and wave action. These pressures have resulted in severe coastline retreat. It has been generally proved that mangroves can decrease the wave energy (Kathiresan and Rajendran, 2005). Although mangroves may not completely halt the coastal erosion, the presence of mangroves reduces the erosion rate (Thampanya et al., 2006). Department of Irrigation and Drainage (DID) of Malaysia (2006) reported that $1414.5 \mathrm{~km}, 29 \%$, of Malaysian shorelines face erosion impacts. The area of mangrove forests continues to decline at a rate of $1 \%$ per year (Gong and Ong, 1990) which means natural rehabilitation process is not capable of effectively recovering mangroves from degradation.

Rehabilitation efforts may be more successful at sites where mangroves previously existed, but the topography of a degraded site may be changed due to erosion/accretion and consequently the hydrologic regime could be altered. Therefore, normal hydrology assessment (depth, duration, and frequency of inundation) of target mangrove species is the most important factor in a mangrove restoration project (Lewis, 2005). In designing a successful restoration project, special attention must be paid to environmental conditions (e.g. hydrology, wave energy, salinity regime, soil and water $\mathrm{pH}$, soil texture, nutrient concentration, elevation, and slope) required by existing natural mangrove species in an adjacent reference site (Elster, 2000; Gilman and Ellison, 2007).

The primary objective ofmangrove rehabilitation projects is often to restore structure and functionality of degraded mangroves to a "least disturbed condition" (Lewis, 2005; Gilman and Ellison, 2007). The term "functionality" is taken to mean the ability of restored mangroves to stabilise shoreline, trap sediments, improve shoreline protection, offer suitable habitat for animals, provide timber and firewood, and promote aesthetic value of coastal areas, in a similar 
way to natural mangroves (Bosire et al., 2008). The current study is aimed to present an integrated approach to mangrove restoration, and its key objectives are: (1) to improve sediment deposition on the restoration site in order to raise the sea floor (datum recovery) to the elevation that provides the correct hydrologic regime; and (2) to restoremangroves to create a sustainable ecosystemthat functions at an equivalent level to the adjoining natural mangrove ecosystem. To achieve this purpose, the SungaiHaji Dorani (SgHj Dorani) beachwas selected on which irreversible land use, over-exploitation of mangrove forests, and mismanagement over the past decades have deteriorated the beach to the point that it has been classified in the critical category by DID (2006).

Description of the study area

Environmental conditions

$\mathrm{Sg} \mathrm{Hj}$ Dorani is located $90 \mathrm{~km}$ to the north of Kuala Lumpur, near Sabak Bernam, on the west coast of Peninsular Malaysia (Fig. 1). It is nearly $2.6 \mathrm{~km}$ long and has a 1:100 foreshore slope. Bernam River and Perak River both carry huge amount of sediments to the Malacca Strait (Cleary and Goh, 2000), meet the coastline some $40 \mathrm{~km}$ away from $\mathrm{Sg} \mathrm{Hj}$ Dorani. Littoral currents distribute this fluvial discharge over the shoreline to the $\mathrm{Sg} \mathrm{Hj}$ Dorani beach where destruction of the coastal forest decreases the chance of sediment deposition. Therefore, it was anticipated that mangrove replanting in this area could help with trapping the sediment.

Recently, the muddy beach of $\mathrm{Sg} \mathrm{Hj}$ Dorani has become subject to engineering and ecological projects on account of the beach critical situation caused by human induced alterations. In 1977, to protect the coastal area against tidal inundation a dyke was constructed along the shoreline by DID. The dyke faced severe erosion during the 1980s. Hence, in 1991, during maintenance, a length of $1.5 \mathrm{~km}$ of the seaward slope of the dyke was covered with concrete armour units along the Northern and the Central beaches where the dyke was exposed to the wave action. In order to protect the concrete armour layer from the toe scour, a 5-m-wide rock mat was constructed in front of the toe along the Central beach. Today, the dyke has a crest elevation of $3.20 \mathrm{~m}$ above MSL (mean sea level), and the toe elevation is averaged at about p0.75 m MSL. Although the embankment has strongly prevented the shoreline from retreating and protected the agricultural land against flooding, its construction process accelerated mangrove degradation. Moreover, this barrier broke the link between the mangrove and backshore and prevents mangroves from migrating landward. Consequently, the mangrove area has been sandwiched between the dyke from the landward side, and the wave action from the seaward side. In 2006, D'Muara Marine Park's construction activity along the 
Southern beach destructed the existing mangrove forest in the

recreational area. Currently, the mangrove forest is limited to an

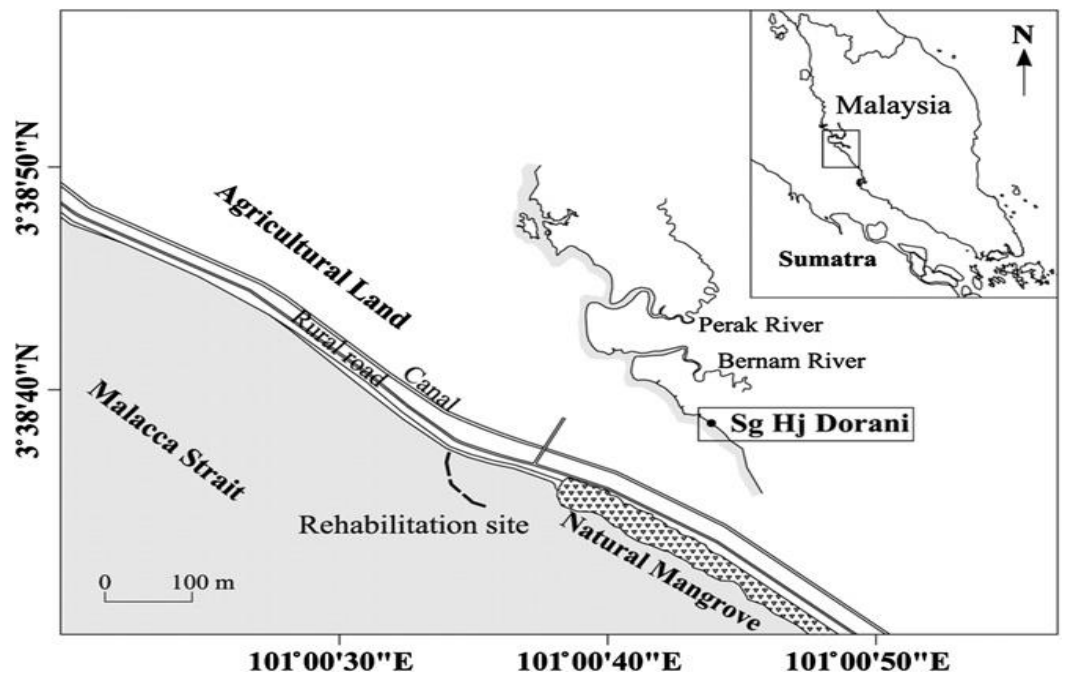

Fig. 1. Study area on the west coast of Peninsular Malaysia.

area between Southern and Central beaches that only covers $800 \mathrm{~m}$ of the $\mathrm{Sg} \mathrm{Hj}$ Dorani beach.

The $\mathrm{Sg} \mathrm{Hj}$ Dorani beach is predominantly covered by mud deposits. Based on a hydrometer analysis with samples taken from the restoration area at depths of $5-100 \mathrm{~cm}$, the mud contains a mixture of $22 \%$ clay ( $<2 \mathrm{~mm}$ ), $56 \%$ silt, $17 \%$ fine sand (coarser than $60 \mathrm{~mm}$ ), and $5 \%$ organic matter on average

\section{Full text available at :}

http://ac.els-cdn.com/S0272771409004971/1-s2.0-S0272771409004971-main.pdf? tid=1b1cd75c-66e4-11e39db1-00000aab0f6c\&acdnat $=1387261744$ d0b0320ca4be7f072b2d6d16561e1a87

\section{http://www.sciencedirect.com/science/article/pii/S0272771409004971}

